\title{
Aspicilia stalagmitica (Megasporaceae) - a new lichen species with isidia-like thalline outgrowths
}

\author{
A. G. Paukov ${ }^{1 *}$, E. A. Davydov² \\ ${ }^{1}$ Ural Federal University, Lenina pr., 51, Ekaterinburg, RF-620000, Russian Federation.E-mail: alexander_paukov@mail.ru \\ ${ }^{2}$ Altai State University, Lenina pr., 61, Barnaul, RF-656049, Russian Federation. E-mail: eadavydov@yandex.ru \\ * Corresponding author
}

Keywords: Altai, Aspicilia, China, ITS, molecular phylogeny, new taxon, Xinjiang.

Summary. Aspicilia stalagmitica Paukov et Davydov from the Altai Mts, a species with isidia-like outgrowths on areoles, is described as new to science. From other species of the genus Aspicilia stalagmitica differs by the following set of characters: short narrow marginal lobes, conidiomata in the isidia-like outgrowths, appressed to almost substipitate apothecia, long picnoconidia, and stictic acid as a main secondary metabolite. A phylogenetic analysis of Aspicilia stalagmitica (ITS) showing its relationships within Aspicilia is presented.

\section{Aspicilia stalagmitica (Megasporaceae) - новый вид лишайника с изидиевидными выростами таллома}

\author{
А. Г. Пауков ${ }^{1 *}$, Е. А. Давыдов ${ }^{2}$ \\ ${ }^{1}$ Уральский федеральныий университет, пр. Ленина, 51, г. Екатеринбург, 620000, Россия \\ ${ }^{2}$ Алтайский государственный университет, пр. Ленина, 61, г. Барнаул, 656049, Россия \\ *Автор для переписки
}

Ключевые слова: Алтай, аспицилия, Китай, молекулярная филогения, новый таксон, Синьцзян, ITS.

Аннотация. Aspicilia stalagmitica Paukov et Davydov - лишайник из северного Китая с изидиевидными выростами на ареолах, описан как новый для науки вид. От других видов рода он отличается следующей совокупностью признаков: короткие и узкие краевые лопасти, изидиевидные выросты, содержащие конидии, сидячие апотеции, длинные пикноконидии и стиктовая кислота в качестве основного вторичного метаболита. Представлены результаты филогенетического анализа с использованием ITS последовательностей, которые показывают положение вида в пределах рода Aspicilia.

\section{Introduction}

Family Megasporaceae (or Aspicilia s. 1.) is remarkable in its morphological diversity and comprises taxa of different life forms from those having immersed thalli to dwarf-fruticose and vagrant species (Sohrabi et al., 2013). Saxicolous and some terricolous representatives of the fruticose life form start their ontogenesis from formation of areolate thalli followed by the development of straight or contorted, simple or branched outgrowths up to several millimeters high (Oxner, 1971). A small number of Aspicilia species develop only tiny isidia-like structures which subsequently never form 
fruticose thalli (Poelt, 1961). During field work in the northern China in 2005 Evgeny Davydov collected several specimens with such morphology, which were recognized as representatives of a previously undescribed species. Here we describe this species as new to science.

\section{Materials and Methods}

\section{Specimens and phenotype studies}

The core material for this study was collected by Evgeny Davydov during the expedition to Xinjiang (China) in 2005 and deposited in herbaria LE, ALTB, UFU, and PE. Morphological observations were made using a dissecting microscope. Crosssections of apothecia and thalli were cut by hand with a razor blade and observed after mounting in water, $\mathrm{K}, \mathrm{N}$ and iodine solutions. Measurements of spores and conidia are presented as follows: (smallest value recorded) $(\mathrm{X}-\mathrm{SE})-\underline{\mathrm{X}}-(\mathrm{X}+\mathrm{SE})$ (largest value recorded), where $\underline{X}$ is the (arithmetic) sample mean, and SE the sample error of mean. The measurements were made with the precision of 0.5 $\mu \mathrm{m}$.
Secondary products were analyzed by applying standard thin-layer chromatography techniques (TLC, Culberson, Kristinsson, 1970). Solvent A (toluene : 1,4-dioxane : acetic acid, $180: 45: 5$ ) and $\mathrm{C}$ (toluene : acetic acid, $170: 30)$ systems were used for the TLC analysis.

\section{Sequences and phylogenetic reconstructions}

To test phylogenetic relations to other species, nuclear internal transcribed spacers and 5.8S rDNA (ITS) sequences of the putative new species and other sequences retrieved from the NCBI database (GenBank) were used for a molecular phylogenetic analysis. Our sampling comprised 14 species of Aspicilia including a putative new species, species of Oxneriaria, Lobothallia and Circinaria, as well as Ochrolechia parella (L.) A. Massal as an outgroup. This selection is based on the studies of Nordin et al. (2007, 2008, 2010), Kondratyuk et al. (2016), Haji Moniri (2017) and a five-gene analysis by Miądlikowska et al. (2014). The information on the samples with the GenBank accession numbers are given in Table.

Table

Species of lichens used in the phylogenetic analysis in this study together with specimen information and GenBank Accession numbers. New specimen and its sequence are in bold.

\begin{tabular}{|c|c|c|c|c|}
\hline Species & Origin & $\begin{array}{c}\text { Collection number or } \\
\text { reference }\end{array}$ & $\begin{array}{c}\text { ITS GenBank } \\
\text { Accession number }\end{array}$ & Reference \\
\hline $\begin{array}{l}\text { Aspicilia } \\
\text { abbasiana }\end{array}$ & China & $\begin{array}{c}\text { Ismayil et Abbas } \\
20111154\end{array}$ & KM609324 & $\begin{array}{c}\text { Ismayil et al., 2015; } \\
\text { Kondratyuk et al., } 2016\end{array}$ \\
\hline A. berntii & Norway & Nordin 6392 & EU502747 & Nordin et al., 2008 \\
\hline A. blastidiata & Russia & $\begin{array}{c}\text { Paukov } \\
\text { AGP20111009-01 }\end{array}$ & KX129963 & $\begin{array}{c}\text { Paukov et al., 2015, } \\
2017\end{array}$ \\
\hline A. blastidiata & Russia & $\begin{array}{c}\text { Paukov } \\
\text { AGP20120801-01 }\end{array}$ & KX159286 & $\begin{array}{c}\text { Paukov et al., } 2015 \text {, } \\
2017\end{array}$ \\
\hline A. cinerea & France & Roux 23869 & JF703118 & Roux et al., 2011 \\
\hline A. cinerea & France & Roux 25015 & JF710311 & Roux et al., 2011 \\
\hline A. cuprea & USA & Owe-Larsson 9112 & EU057902 & Nordin et al., 2007 \\
\hline A. dudinensis & Sweden & Nordin 6036 & EU057906 & Nordin et al., 2007 \\
\hline A. epiglypta & Sweden & Nordin 6303 & EU057907 & Nordin et al., 2007 \\
\hline A. epiglypta & Sweden & Nordin 6305 & HQ259261 & Nordin et al., 2011 \\
\hline A. fluviatilis & Sweden & Nordin 6188 & HQ259264 & Nordin et al., 2011 \\
\hline A. goettweigensis & Austria & Vondrák 14026 & KX159289 & Paukov et al., 2017 \\
\hline A. goettweigensis & Russia & Paukov AGP20120513-03 & KX159292 & Paukov et al., 2017 \\
\hline A. granulosa & Sweden & Nordin 6174 & HQ259265 & Nordin et al., 2011 \\
\hline A. stalagmitica & China & Davydov 17620 & MT014019 & This paper \\
\hline A. subdepressa & France & Roux 24653 & JF703123 & Roux et al., 2011 \\
\hline A. subepiglypta & Korea & 100857 KoLRI & KY249607 & Kondratyuk et al., 2016 \\
\hline A. subepiglypta & Korea & 110495 KoLRI & KY249608 & Kondratyuk et al., 2016 \\
\hline A. subradians & Sweden & Nordin 5984 & HQ259267 & Nordin et al., 2011 \\
\hline A. subradians & Finland & Nordin 6370 & HQ259268 & Nordin et al., 2011 \\
\hline A. verrucigera & Sweden & Tibell 22669 & EU057939 & Nordin et al., 2007 \\
\hline Circinaria esculenta & Kazakhstan & $\begin{array}{l}\text { Ivanov s. n. } \\
\text { (UFU L-1743) }\end{array}$ & MK347507 & Paukov et al., 2019 \\
\hline
\end{tabular}


Table (end)

\begin{tabular}{|l|c|c|c|c|}
\hline \multicolumn{1}{|c|}{ Species } & Origin & $\begin{array}{c}\text { Collection number or } \\
\text { reference }\end{array}$ & $\begin{array}{c}\text { ITS GenBank } \\
\text { Accession number }\end{array}$ & Reference \\
\hline C. fruticulosa & Russia & $\begin{array}{c}\text { Paukov 3074 } \\
\text { (UFU L-3256) }\end{array}$ & MK347508 & Paukov et al., 2019 \\
\hline $\begin{array}{l}\text { Lobothallia } \\
\text { alphoplaca }\end{array}$ & China & Tong 20117616 (SDNU) & JX499233 & Kou et al., 2013 \\
\hline L. praeradiosa & China & Mamut s. n. (XJU) & KT180160 & $\begin{array}{c}\text { Ismayil, Abbas } \\
\text { not published }\end{array}$ \\
\hline L. praeradiosa & Russia & $\begin{array}{c}\text { Paukov AGP20120606-12 } \\
\text { (UFU L-1264) }\end{array}$ & MK347501 & Paukov et al., 2019 \\
\hline Ochrolechia parella & Antarctica & $\begin{array}{c}\text { Park } \\
\text { PCH080112-32 }\end{array}$ & KJ607905 & Park et al., 2015 \\
\hline $\begin{array}{l}\text { Oxneriaria } \\
\text { dendroplaca }\end{array}$ & Finland & Nordin 6366 & HQ259260 & Nordin et al., 2011 \\
\hline O. mashiginensis & Sweden & Nordin 5790 & EU057912 & Nordin et al., 2007 \\
\hline O. permutata & Sweden & Nordin 6039 & EU057921 & Nordin et al., 2007 \\
\hline O. permutata & Sweden & Nordin 5980 & EU057930 & Nordin et al., 2008 \\
\hline O. rivulicola & Sweden & Nordin 5957 & EU057922 & Nordin et al., 2007 \\
\hline O. supertegens & Norway & Owe-Larsson 9002 & EU057936 & Nordin et al., 2007 \\
\hline O. supertegens & Sweden & Nordin 6023 & EU057938 & Nordin et al., 2007 \\
\hline O. verruculosa & Norway & Owe-Larsson 9007 & EU057940 & Nordin et al., 2007 \\
\hline O. verruculosa & Sweden & Nordin 5942 & EU057942 & Nordin et al., 2007 \\
\hline O. virginea & Sweden & Nordin 6017a & HQ259270 & Nordin et al., 2011 \\
\hline O. virginea & Svalbard & Ebbestad SvL1:1 & HQ259271 & Nordin et al., 2011 \\
\hline
\end{tabular}

Methods used for DNA extraction, amplification and sequencing follow Davydov et Yakovchenko (2017). An ITS 534 bp matrix were aligned using the MAFFT algorithm (Katoh et al., 2005) as implemented on the GUIDANCE web server (Sela et al., 2015). Optimal substitution models were inferred separately for ITS1, 5.8S, and ITS2 using PartitionFinder, version 1.1.1 (Lanfear et al., 2012): the General time reversible parameter with gamma distribution site specific rates $(G T R+G)$ for the ITS1+ITS2 partition, and the Kimura 2-parameter with proportion of invariable sites $(\mathrm{K} 80+\mathrm{I})$ for the 5.8S partition. Bayesian inference with the Markov chain Monte Carlo (BMCMC) method (Larget, Shimon, 1999) was performed using MrBayes 3.2.3 (Ronquist et al., 2012). Three parallel Bayesian analyses were run using six chains and every 200th generation was sampled. Convergence of the chains was inferred by calculating the average standard deviation of split frequencies every 100,000 generations using a burn-in fraction of 0.5 , and the runs terminated when the standard deviation of split frequencies dropped below 0.001 . This was the case after $7.1 \mathrm{M}$ generations. The first $50 \%$ of the trees were discarded as burn-in and a $50 \%$ majority rule consensus tree calculated from the remaining trees of three runs with the sumt command implemented in MrBayes 3.2.3. The most likely tree and 1000 rapid bootstrap replicates were calculated using RAxML 8.0.26 (Stamatakis, 2014) by raxmlGUI software version 1.3.1 (Silvestro, Michalak, 2012) applying the GTRGAMMA model of substitution to the subsets. The tree topologies were taken from RAxML. Bootstrap support values and BMCMC posterior probability were noted onto the best scoring tree (Fig. 1).

\section{Results}

An ITS sequence was successfully obtained from one specimen of the putative new species, described below as Aspicilia stalagmitica. The Bayesian 50\% majority-rule consensus tree had the same topology as the maximum likelihood tree generated by RAxML. The phylograms are combined in Fig. 1. According to the ITS sequence the new taxon belongs to Aspicilia and is the closest relative to the NorthAmerican Aspicilia cuprea Owe-Larss. et A. Nordin. These two taxa form a clade well-supported by MrBayes (0.97PP), but only weakly by RAxML (62 $\%$ BS) and rather long branches lengths. The sister clade contains the type species of the genus, Aspicilia cinerea (L.) Körb. 


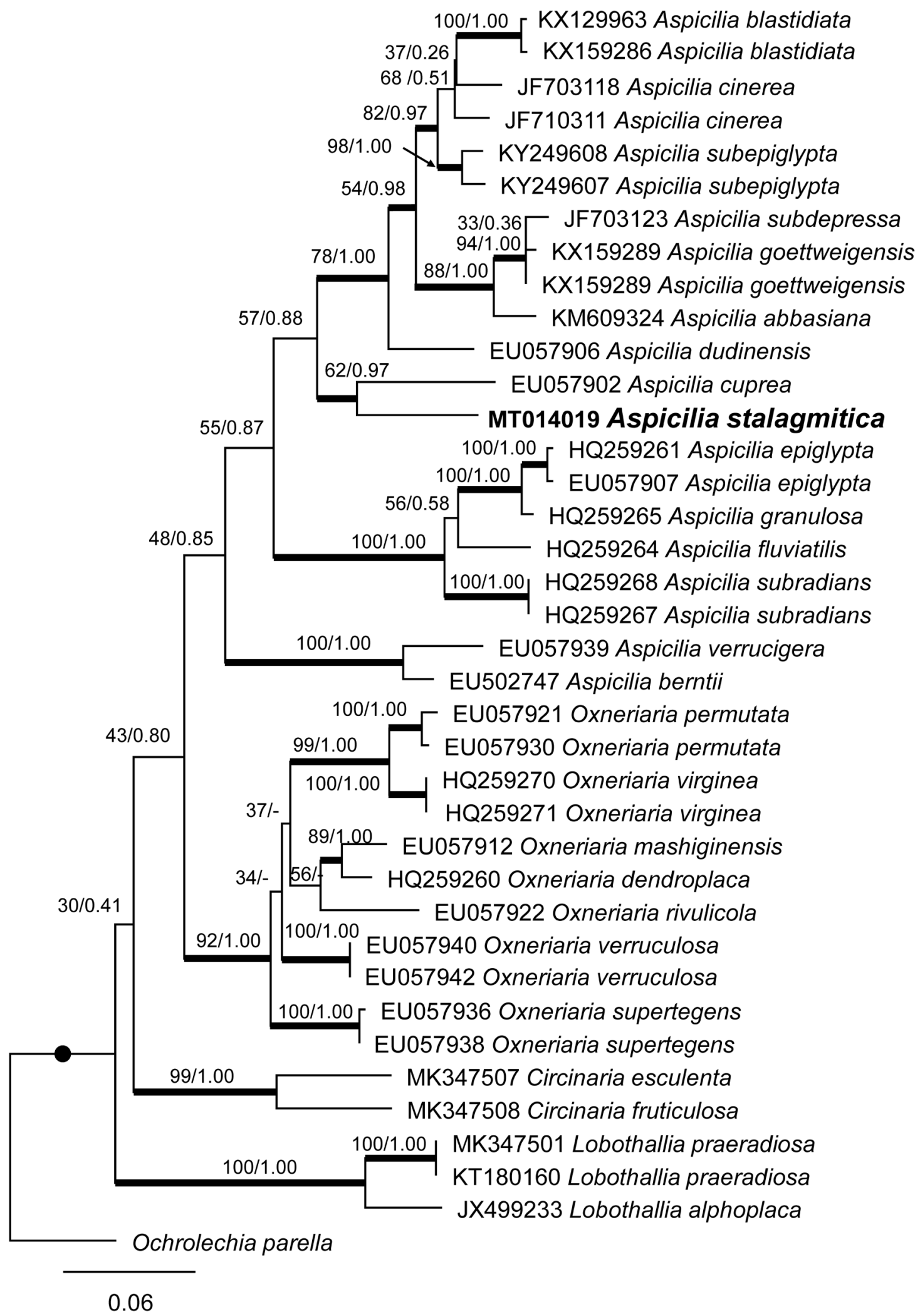

Fig. 1. Maximum likelihood (ML) phylogeny of selected Aspicilia ITS sequences. The reliability of each branch was tested by ML and Bayesian methods. Numbers at tree nodes indicate ML bootstrap percentages (left) and Bayesian inference with the Markov chain Monte Carlo (BMCMC) posterior probabilities (right). Thicker branches indicate when the bootstrap value of $\mathrm{ML}$ is $\geq 70 \%$ or the BMCMC posterior probability is $\geq 0.95$. Accession numbers are given to serve as operational taxonomic unit (OTU) names (see Table). Originally produced sequence is marked in bold. Ochrolechia parella was used as an outgroup. Branch lengths represent the estimated number of substitutions per site assuming the respective models of substitution. Exception is the branch with a black dot, which was shortened to reduce the overall figure size. 


\section{The species \\ Aspicilia stalagmitica Paukov et Davydov, sp.} nov.

MycoBank No.: MB 834291

Aspicilia with a thin, indistinctly lobate, areolate, grey thallus with isidia-like outgrowths usually containing conidiomata. Lobes short and narrow or absent, areoles angular, apothecia sessile, conidia long, 19-33 $\mu \mathrm{m}$. Main secondary metabolite stictic acid.

Type: "China, Xinjiang, Mongolsky Altai range, SW vicinity of Altai City, granite rocks near the road, $47^{\circ} 47^{\prime} 49^{\prime \prime} \mathrm{N}, 8^{\circ} 04^{\prime} 49^{\prime \prime} \mathrm{E}$, elev. $900 \mathrm{~m}$, on rocks. 4 VIII 2005. E. A. Davydov. № 17620" (holo LE-L15292, iso - ALTB, UFU-L3488) (Fig. 2).
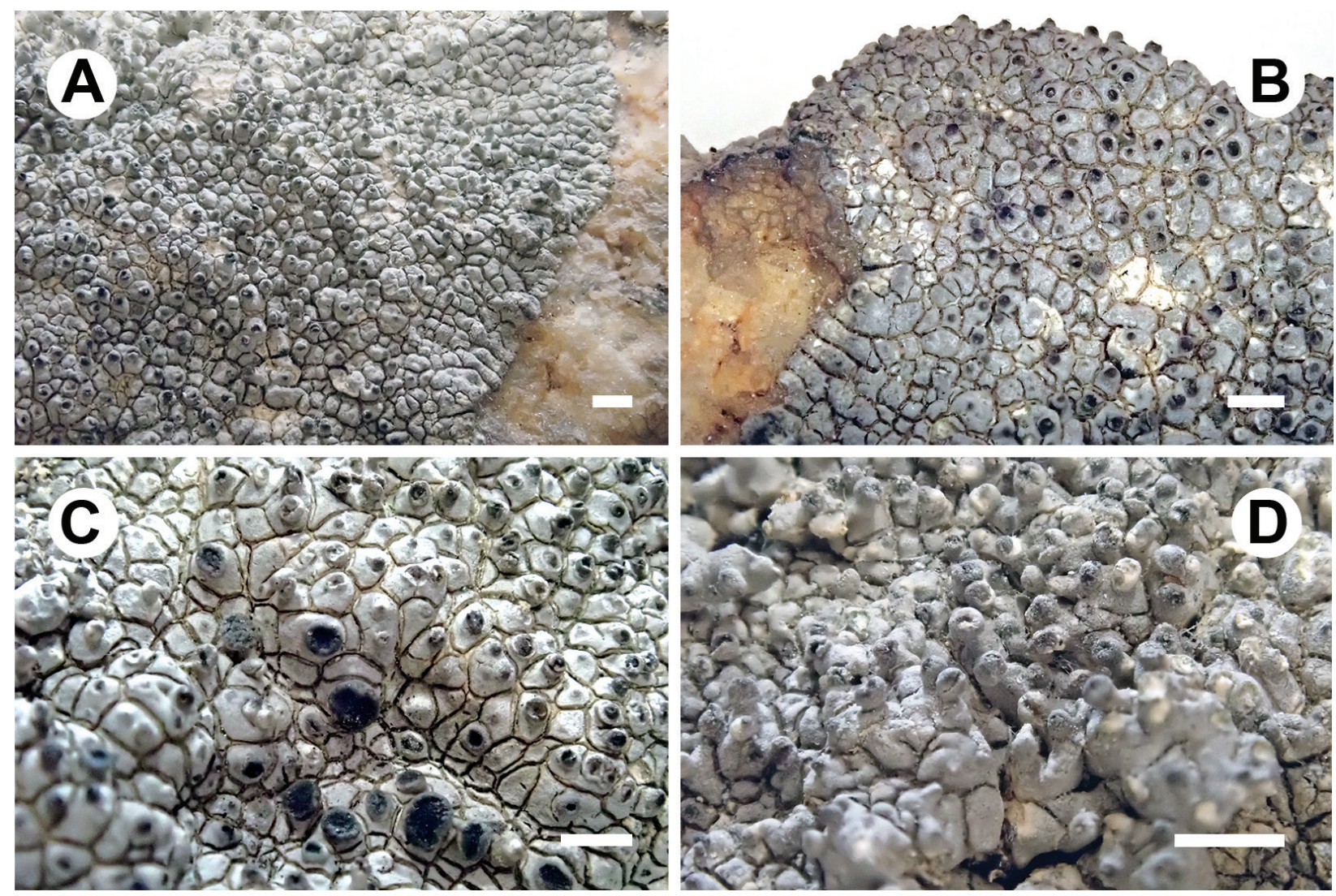

Fig. 2. Aspicilia stalagmitica (holotype): A - thallus; B - outer part of the thallus with young projections, C - thallus with apothecia; D - projections in the central part of the thallus. Scale $=1 \mathrm{~mm}$.

Life habit lichenized. Thallus grey, up to 1.5 $\mathrm{mm}$ thick, indistinctly lobate at the periphery and areolate in the central part. Lobes relatively short and narrow, $0.5-1.5 \times 0.4-0.5 \mathrm{~mm}$ (length $\times$ width), moderately convex, inconspicuous in some thalli. Areoles $0.5-1.7 \mathrm{~mm}$, irregular in form, angular, moderately convex, with isidia-like outgrowths. The outgrowths are sphaeric, one, two, rarely more per areola, constricted at the bases, $0.25-0.5 \mathrm{~mm}$, brittle, in the central parts of thalli occasionally cylindric, up to $0.75 \mathrm{~mm}$ high, blackish at the tops, commonly containing pycnidia with blackish spot-like or elongated ostioles. Upper cortex paraplectenchymatous, 30-50 $\mu \mathrm{m}$ high, cells $7-10$ $\mu \mathrm{m}$. Medulla $\mathrm{I}-, \mathrm{K}+$ yellow, with rare needlelike crystals. Photobiont layer 50-70 $\mu \mathrm{m}$ thick, interrupted by narrow hyphal bands $5-10 \mu \mathrm{m}$.
Photobiont chlorococcoid, algae 7-20 $\mu \mathrm{m}$ diam. Prothallus absent. Vegetative propagules absent. Apothecia lecanorine, 1 per areole, developing from the outgrowths, appressed, later sessile, constricted at the base, rounded or elliptic in outline, 0.3-0.7 $\mathrm{mm}$ diam.; disc initially dot-like, later wide, flat, not pruinose or weakly white pruinose, blackish, surrounded by a projecting thalline margin. Margin $0.10-0.15 \mathrm{~mm}$, lead-grey, darker than the thallus. Exciple of radiating hyphae, poorly recognizable under the hypothecium, widening to $25-30 \mu \mathrm{m}$ in the uppermost part. Hymenium hyaline, 100-112 $\mu \mathrm{m}$ high, fleetingly bluish in I; paraphyses predominantly submoniliform, rarely moniliform with 2-3 apical cells thickened; epihymenium brownish, $\mathrm{N}+$ greenish, 57-62 $\mu \mathrm{m}$ high. Hypothecium hyaline, I+ weakly bluish, $100-120 \mu \mathrm{m}$ in the central part. 
Asci clavate, Aspicilia-type; ascospores broadly ellipsoid, hyaline, aseptate (19.0-)21.0-21.5-22.0 $(-23.0) \times(12.0-) 13.5-14.0-14.5(-16.0) \mu \mathrm{m}(\mathrm{n}=$ 10). Pycnidia common, in isidia-like projections, with punctiform or elongated ostiole; conidia bacilliform, hyaline, curved or straight, aseptate $(19.0-) 24.5-25.0-25.5(33.0) \mu \mathrm{m}$ long $(\mathrm{n}=56)$.

Chemistry. Thallus $\mathrm{K}+$ yellow, $\mathrm{C}-$; medulla $\mathrm{K}+$ yellow, $\mathrm{C}-$; stictic acid complex by TLC, norstictic acid as a minor substance in all specimens.

Etymology. The name refers to the vertical outgrowths on areoles which resemble stalagmites.

Ecology. Aspicilia stalagmitica was found in arid conditions on exposed siliceous rocks (granite and schistose) in steppe communities at elevations $880-1600 \mathrm{~m}$ a. s. 1. The following species cooccurred with Aspicilia stalagmitica: Acarospora bohlinii H. Magn., A. irregularis H. Magn., Aspicilia cinerea (L.) Körb., Candelariella vitellina (Ehrh.) Müll. Arg., Circinaria maculata (H. Magn.) Q. Ren, C. hoffmanniana (S. Ekman et Fröberg ex R. Sant.) A. Nordin, Immersaria cupreoatra (Nyl.) Calat. et Rambold, Lecanora argopholis (Ach.) Ach., Protoparmeliopsis garovaglii (Körb.) Arup et al., Rusavskia dasanensis S. Y. Kondr. et al., and Xanthoparmelia delisei (Duby) O. Blanco et al.

Distribution. The species is known from three localities in the Xinjiang autonomous region of China.

Paratypes: China, Xinjiang, Mongolsky Altai range, "left bank of the Kran River, Altai City, S slope of Mt., on rocks, elev. 880 m. 47 $499^{\prime} 52^{\prime \prime N}$, $88^{\circ} 08^{\prime} 08^{\prime \prime E} .31$ VII 2005. E. A. Davydov. № 18943” (ALTB, UFU); "valley of Irtysh River at $10 \mathrm{~km} \mathrm{E}$ settlement Kektogoy, steppe slope, on rocks, elev. 1300-1600 m. 47 $13^{\prime} 40^{\prime \prime} \mathrm{N}, 8^{\circ} 55^{\prime} 18^{\prime \prime}$ E. 7 VIII 2005. E. A. Davydov. № 17618, 17619” (ALTB, UFU).

\section{Discussion}

Aspicilia stalagmitica is a peculiar species which can be easily distinguished from other Aspicilia s. 1 . by its isidia-like outgrowths, which contain conidiomata. Along with this character the species has long pycnoconidia, up to $33 \mu \mathrm{m}$, and contains the stictic acid complex. All the found specimens contain vertical outgrowths but the combination of long conidia and stictic acid may be a separate character which segregates this species from all known taxa within the genus.

According to the ITS phylogeny the closest species to Aspicilia stalagmitica is A. cuprea, which is known from the USA, California. It differs from the former by its similarity to Aspiciliella cupreoglauca (B. de Lesd.) Zakeri et al. (Zakeri et al., 2019), i. e. its brown thallus, immersed apothecia, and large spores $(20-31 \times 11-17 \mu \mathrm{m})$ (Owe-Larsson et al., 2007). The conidium length is a character, which segregates both Aspicilia cuprea and A. stalagmitica from the Aspicilia cinerea-group. Only Aspicilia dudinensis (H. Magn.) Oxner from this group has a conidium length that considerably overlaps with Aspicilia stalagmitica and A. cuprea (Nordin et al., 2008; Paukov et al., 2017), but never reaches $30 \mu \mathrm{m}$. Other similar species with conidia exceeding this range belong to Oxneriaria (Oxneriaria rivulicola (H. Magn.) S. Y. Kondr. et L. Lőkös, and O. supertegens (Arnold) S.Y. Kondr. et L. Lőkös), but lack secondary metabolites.

Compared to species with isidia-like projections, Aspicilia stalagmitica is most similar to Oxneriaria mashiginensis (Zahlbr.) S.Y. Kondr. et L. Lőkös, which, however, differs by its darker thalli, smaller spores $(14-18 \times 9-11 \mu \mathrm{m})$ and shorter conidia $(12.5-19.0 \mu \mathrm{m})$, and by containing substictic acid. Further, the outgrowths usually disintegrate into soredia and do not contain conidiomata (Nordin et al., 2008).

\section{Acknowledgements}

Evgeny Davydov thanks Dr Wen-Li Chen for organizing the expedition to China. Alexander Paukov would like to thank RFBR (project 18-04-00414) and the Ministry of Education and Science of the Russian Federation (agreement no. 02.A03.21.0006) for financial support. We are grateful to Anders Nordin (Museum of Evolution, Uppsala University) whose comments have greatly improved the manuscript.

\section{REFERENCES}

Culberson C. F., Kristinsson, H. D. 1970. A standardized method for the identification of lichen products. J. Chromatogr. 46: 85-93. 
Davydov E. A., Yakovchenko L. S. 2017. Rhizocarpon smaragdulum, a new monosporic yellow-thalline species and some additional species of the genus Rhizocarpon from the Altai Mountains (Siberia). Lichenologist 49: 457-466. DOI: $10.1017 / \mathrm{s} 0024282917000469$

Haji Moniri M., Gromakova A. B., Lőkös L., Kondratyuk, S. Y. 2017. New members of the Megasporaceae (Pertusariales, lichen-forming Ascomycota): Megaspora iranica spec. nova and Oxneriaria gen. nova. Acta Bot. Hung. 59(3-4): 343-370. DOI:10.1556/034.59.2017.3-4.5

Ismayil G., Abbas A., Guo S.-Y. 2015. Aspicilia volcanica, a new saxicolous lichen from Northeast China. Mycotaxon 130(2): 543-548. DOI:10.5248/130.543

Katoh K., Kuma K., Toh H., Miyata T. 2005. MAFFT version 5: improvement in accuracy of multiple sequence alignment. Nucl. Acids Res. 33: 511-518. DOI: 10.1093/nar/gki198

Kondratyuk S.Y., Lökös L., Park J.-S., Jang S.-H., Jeong M.-H. 2016. New Aspicilia species from South Korea proved by molecular phylogeny with a key to the Eastern Asian aspicilioid lichens. Stud. Bot. Hung. 47(2): $227-249$. DOI:10.17110/StudBot.2016.47.2.227

Kou X.-R., Li S.-X., Ren Q. 2013. Three new species and one new record of Lobothallia from China. Mycotaxon 123: 241-249. DOI: $10.5248 / 123.241$

Lanfear R., Calcott B., Ho S. Y. W., Guindon S. 2012. PartitionFinder: combined selection of partitioning schemes and substitution models for phylogenetic analyses. Molec. Biol. Evol. 29: 1695-1701.

Larget B., Shimon D. 1999. Markov chain Monte Carlo algorithms for the Bayesian analysis of phylogenetic trees. Molec. Biol. Evol. 16: 750-759.

Miadlikowska J., Kauff F., Högnabba F., Oliver J.C., Molnár K., Fraker E., Gaya E., Hafellner J., Hofstetter V., Gueidan C., Otálora M.A.G., Hodkinson B., Kukwa M., Lücking R., Björk C., Sipman H.J.M., Burgaz A.R., Thell A., Passo A., Myllys L., Goward T., Fernández-Brimem S., Hestmark G., Lendemer J., Lumbsch H.T., Schmull M., Schoch C. L., Sérusiaux E., Maddison D. R., Arnold A. E., Lutzoni F., Stenroos S. 2014. A multigene phylogenetic synthesis for the class Lecanoromycetes (Ascomycota): 1307 fungi representing 1139 infrageneric taxa, 317 genera and 66 families. Molec. Phylogen. Evol. 79: 132-168.

Nordin A., Owe-Larsson B., Tibell L. 2011. Two new Aspicilia species from Fennoscandia and Russia. Lichenologist 43(1): 27-37.

Nordin A., Savić S., Tibell L. 2010. Phylogeny and taxonomy of Aspicilia and Megasporaceae. Mycologia 102(6): 1339-1349. DOI: 10.3852/09-266

Nordin A., Tibell L., Owe-Larsson B. 2007. A preliminary phylogeny of Aspicilia in relation to morphological and secondary product variation. In: A. Frisch, U. Lange and B. Staiger: Lichenologische Nebenstunden. Contributions to Lichen Taxonomy and Ecology in Honour of Klaus Kalb. Bibliotheca Lichenologica 96. Berlin-Stuttgart: J. Cramer in der Gebrüder Borntraeger Verlagsbuchhandlung. Pp. 247-266.

Nordin A., Tibell L., Owe-Larsson B. 2008. Aspicilia berntii, a new name for a poorly known species. Lichenologist 40(2): 127-133. DOI:10.1017/S0024282908007573

Owe-Larsson B., Nordin A., Tibell L. 2007. Aspicilia. In: T. H. Nash, C. Gries, F. Bungartz "Lichen Flora of the Greater Sonoran Desert Region”. Vol. 3. Tempe: Lichens Unlimited, Arizona State University. Pp. 61-108.

Oxner A. N. 1971. Aspicilia. In: Handbook of the Lichens of the USSR. Leningrad: Nauka. Pp. 146-217. [In Russian] (Окснер A. Н. Aspicilia // Определитель лишайников СССР. Л.: Наука, 1971. С. 146-217).

Park C. H., Kim K. M., Elvebakk A., Kim O. S., Jeong G., Hong S. G. 2015. Algal and fungal diversity in Antarctic lichens. J. Eukaryot. Microbiol. 62(2): 196-205. DOI: 10.1111/jeu.12159

Paukov A. G., Davydov E. A., Nordin A., Roux C., Şenkardeşler A., Sohrabi M., Vondrák J., Frolov I. V., Teptina A. Y., Shiryaeva A. S. 2019. Three new species, new combinations and a key to known species of Lobothallia (Megasporaceae). Lichenologist 51(4): 301-322. DOI: 10.1017/S0024282919000264

Paukov A., Nordin A., Tibell L., Frolov I., Vondrák J. 2017. Aspicilia goettweigensis (Megasporaceae, lichenized Ascomycetes) - a poorly known and overlooked species in Europe and Russia. Nordic J. Bot. 35(5): 595-601. DOI: 10.1111/njb.01222

Paukov A. G., Teptina A. Yu., Pushkarev E. V. 2015. Heavy metal uptake by chemically distinct lichens from Aspicilia spp. growing on ultramafic rocks. Austral. J. Bot. 63(2): 111-118. DOI:10.1071/BT14255

Poelt J. 1961. Mitteleuropaische Flechten VII. Mitteil. der Bot. Staatssammlung München 4: 171-197.

Ronquist R., Teslenko M., van der Mark P., Ayres D. L., Darling A., Höhna S., Larget B., Liu L., Suchard M. A., Huelsenbeck J. P. 2012. MrBayes 3.2: efficient bayesian phylogenetic inference and model choice across a large model space. Syst. Biol. 61: 539-542.

Roux C., Nordin A., Tibell L., Sohrabi M. 2011. Quelques espèces d'Aspicilia peu connues ou nouvelles des Pyrénées-Orientales (France). Bulletin de la Société Linnéenne de Provence, num. spéc. 14: 177-227.

Sela I., Ashkenazy H., Katoh K., Pupko T. 2015. GUIDANCE2: accurate detection of unreliable alignment regions accounting for the uncertainty of multiple parameters. Nucleic Acids Research, 2015 Jul 1; 43 (Web Server issue): W7-W14. DOI: 10.1093/nar/gkq443 
Silvestro D., Michalak I. 2012. RaxmlGUI: A graphical front-end for RAxML. Organisms Diversity Evol. 12: 335-337.

Sohrabi M., Stenroos S., Myllys L., Sochting U., Ahti T., Hyvönen J. 2013. Phylogeny and taxonomy of the 'manna lichens'. Mycol. Progr. 12, 2: 231-269. DOI: 10.1007/s11557-012-0830-1

Stamatakis A. 2014. RAxML version 8: a tool for phylogenetic analysis and post-analysis of large phylogenies. Bioinformatics 30: 1312-1313. DOI: 10.1093/bioinformatics/btu033

Zakeri Z., Sipman H., Paukov A., Otte V. 2019: Neotypification of Aspiciliella cupreoglauca and lectotypification and synonymization of Aspicilia reticulata (Megasporaceae, Ascomycota). Lichenologist 51(1): 97-99. DOI: $10.1017 / \mathrm{S} 0024282918000476$ 